\title{
PALEONTOLOGICAL SOCIETY SPECIAL PUBLICATIONS
}

The Paleontological Society publishes two series of topical publications. Short Course Notes are published each year in association with the Society's annual short course, held with the Annual Meeting of the Geological Society of America. The Special Publications series includes the proceedings of symposia and other events sponsored by the Society.

Short Course Notes

Echinoderms-edited by T.W. Broadhead and J.A. Waters, 1980, University of Tennessee Studies in Geology 3, 235 p., out of print.

Lophophorates-organized by J.T. Dutro, Jr. and R.S. Boardman, 1981, University of Tennessee Studies in Geology 5, 253 p., out of print.

Foraminifera-organized by M.A. Buzas and B.K. Sen Gupta, 1982, University of Tennessee Studies in Geology 6, 219 p., out of print.

Sponges and Spongiomorphs--organized by J.K. Rigby and C.W. Stearn, 1983, University of Tennessee Studies in Geology 7, 220 p., out of print.

Mammals-organized by P.D. Gingerich and C.E. Badgley, 1984, University of Tennessee Studies in Geology 8, 220 p., $\$ 12$.

Mollusks-organized by D.J. Bottjer, C.S. Hickman, and P.D. Ward, 1985, University of Tennessee Studies in Geology 13, 308 p., \$12.

Land Plants-organized by R.A. Gastaldo, 1986, University of Tennessee Studies in Geology 15, 226 p., \$12.

Fossil Prokaryotes and Protists--organized by J.H. Lipps, 1987, University of Tennessee Studies in Geology 18, 303 p., $\$ 8$.

Molecular Evolution and the Fossil Record--organized by Bruce Runnegar and J.W. Schopf, 1988, Short Courses in Paleontology 1, 167 p., \$12.

The Age of Dinosaurs-organized by Kevin Padian and Daniel J. Chure, K. Padian, ed., 1989, Short Courses in Paleontology 2, 210 p., \$15.

Arthropod Paleobiology--organized by Norman L. Gilinsky and Phillip W. Signor, N.L. Gilinsky and P.W. Signor, eds., 1991, Short Courses in Paleontology 3, 315 p., \$15.

Trace Fossils-organized by Christopher G. Maples and Ronald R. West, C.G. Maples and R.R. West, eds., 1992, Short Courses in Paleontology 5, 236 p., \$15.

Taphonomic Approaches to Time Resolution in Fossil Assemblages--organized by S. M. Kidwell and A.K.

Behrensmeyer, S.M. Kidwell and A.K. Behrensmeyer, eds., 1993, Short Courses in Paleontology 6, 302 p., $\$ 15$.

Special Publications

The Evolution-Creation Controversy: Perspectives on Religion, Science, and Education--A Handbook--organized by R.A. Gastaldo and W.F. Tanner, 1984, Special Publication 1, 154 p., \$6.50.

Paleoecology and Taphonomy of Pleistocene to Recent Intertidal Deposits, Gulf of California-K.W. Flessa, ed., 1987, Special Publication 2, 240 p., \$12.50.

Methods and Applications of Plant Paleoecology--W.A. DiMichele and S.L. Wing, eds., 1988, Special Publications 3, 171 p., $\$ 12.50$.

Paleotechniques--R.M. Feldman, R.E. Chapman, and J.T. Hannibal, eds., 1989, Special Publications 4, 358 p., \$20.

Paleocommunity Temporal Dynamics: the Long-Term Development of Multispecies Assemblies-W. Miller, III, ed., 1990, Special Publications 5, 421 p., \$20.

Fifth North American Paleontological Convention Abstracts and Program--S. Lidgard and P.R. Crane, eds., 1992, Special Publications 6, 392 p., \$5.

All publications are available by mail order from:

\author{
The Paleontological Society \\ c/o Department of Geological Sciences \\ University of Tennessee \\ Knoxville, TN 37996-1410 \\ USA
}

A check or institutional purchase order must accompany the order. Payment is to be made in SUS to the Paleontological Society. Orders will be shipped 4th class mail; overseas orders should add $\$ 1.50$ US for surface mail. Prices quoted are as of October 1, 1992 and are subject to change. 